\title{
Presenting Vocabulary Sessions to Improve the English Competence Skills of Senior High School Students
}

\author{
Titis Pawiyati R. Pramono ${ }^{\mathrm{a}, *}$
}

\author{
${ }^{a}$ SMA Negeri 1 Porong, Sidoarjo, Indonesia \\ *Corresponding author. E-mail address: tiesprp@gmail.com
}

\begin{abstract}
Implementing the National Curriculum in learning activities for students of the first level of senior high, researcher observed the score of the Integrated Four English Skills; Listening, Speaking, Reading, and Writing. Even though has been revised for the third time since has been applied in 2013, the result of the authentic assessments series shows the problems of performing the skills still block the maximum competence during the early semester because of the lack capacity of Mental Lexicon. Because of inadequate vocabulary, some of the students use Bahasa Indonesia to answer the English questions (written or orally) while others write with misword choice, or give no responses. The next steps of the research leads to the importance of vocabulary and this work will try to present some sessions for presenting them to support the compulsory students and teacher's textbooks which actually have been provided in line with the syllabi.
\end{abstract}

Keywords: achievement in four skills, lack of vocabularies, presenting vocabulary sessions.

\section{INTRODUCTION}

Handling classes that adopt the Indonesian National Curriculum of 2013 in the fifth year, ideally, a teacher should have found the best teaching methods for better learning process. The researcher's classes, of students of Class X MIPA 6 and X IPS 3 of a state senior high in Sidoarjo in the First Semester in The Academic Year 2018/2019, had still encountered problems to improve their competence in four Basic English skills; listening, speaking, reading and writing. The lesson plans which used as the vehicle to gain the improvement of the skills should be helped by more acquisition in vocabulary or mental lexicon as the results of the serial authentic assessments showed the importance of the vocabulary level. There are roles Vocabulary, or word meaning, is one of the keys to understand a comprehension or paragraph or statements, so without understanding of words means that a student will not be able to understand a comprehension (Haddad, 2016). Richards and Renandya (2002, p. 255) identify that Vocabulary is a core component of language proficiency and provides much of basis for how well learners speak, listen, read and write.

More specific in listening, Marianne \& Olshtain (2000, p. 102) declares that listening is the most frequently used language skill in everyday life. That is why, problem in this skill may be occurred in the classroom if students don't have sufficient vocabulary to give best response orally and writtenly in top-down processing. Then, the bottom-up processing of students in speech production especially in vocabulary retrieval can also be affected (ibid, p. 165) that they don't know what should say, or in worse situation in the researcher's class, they still depend on the script to perform dialogues. 
The relationship between vocabulary and reading has been a well-established notion among the teachers of English as a foreign language and language teaching theoreticians (SSen \& Kuleli, 2015). Lack of vocabulary still creates problems that some of the points in the passage, text or composition couldn't be coped, and, furthermore, the questions given couldn't be answered properly. Anderson and Freeboy (1981) state that it is general vocabulary knowledge of the reader that the best predicts how well that reader understands the text. Nagy (1988) also states that vocabulary is fundamental comprehension of various texts and that vocabulary teaching should be an integral part of language.

A well-written text, stated by Marianne \& Olshtain (2000), has to conform to more local and specific features, one of them is choosing proper lexical items. Because of the absence of this, the words, phrases or sentences can't be written well, too. Even they have been written, the unity and connectedness within each part of the composition will fail to be understandable. This brings effect to the formative tests that some of students used Bahasa Indonesia to answer some numbers, while others gave miswords choice or leaving some spaces un-replied with the reasons of having no adequate words to write.

Based on the findings in those situations, researcher proposed serial of treatment by presenting sessions of Vocabulary Sessions for pre, whilst or post learning sessions that were given in line with the syllabi which hopefully to complete the textbooks and for further study, the research can be continued to handling a Design Research.

\section{METHOD}

\section{SELECTING APPROACH}

Considering the syllable applied nationally, the approach used here is Scientific Approach with the Four-D Model which is divided into 4 steps: define, design, develop and disseminate. The first and second steps (define and design) will be discussed slightly in this occasion, the third (develop) is going to be focused on the media, as the title mentioned, while the fourth one (disseminate) will be skipped off from the topic of discussion.

\section{PRESENTING THE VOCABULARY SESSIONS}

The vocabulary presented with series of activities before, during or after the classroom's activities that may be vary for each class, depend on the level of the students, difficulty of the items, teachability, and the purpose of the mental lexicon used in the topic/ chapter, whether they are for production or recognition (Thornbury, 2007). The duration may also vary from 1045 minutes, based on the level of difficulty and purpose.

\section{PREPARATION}

Before presenting the activities, firstly, the syllabi of National Curriculum must be considered. In General English of class X of senior high, there are 9 materials for two semesters/ one academic year: Introduction, Compliment, Intention to do something, Descriptive Text, Announcement, Simple Past and Present Perfect Tense, Recount Text of historical incident and Narrative Text (Permendikbud No.37, 2018). The textbooks which released to complete the syllabi, then, must be reviewed to find out which part of the instructional design can be designed for the mental lexicon activities. (Note: there are two textbooks for each level: students' book and teacher's book, and the instructional part is in the one for the teacher). 
The following points will give the detail about the pre- observation and steps to give the serial treatments of mental lexicon.

\section{PARTICIPANTS}

There are two classes of class X (first level in senior high) with 36 students in each class, therefore, there are 72 participants involved in the observation.

Table 1. The gender of participants

\begin{tabular}{|c|l|r|r|r|}
\hline \multirow{2}{*}{ No } & \multicolumn{4}{|c|}{ Name of Class and gender } \\
\cline { 2 - 5 } & \multicolumn{1}{|c|}{ Class } & Male & female & Total \\
\hline 1 & X MIPA 6 & 12 & 24 & 36 \\
\hline 2 & X IPS 3 & 15 & 21 & 36 \\
\hline
\end{tabular}

DEFINE STEP

It is the step to stipulate and define the problems of the four skills. This step is handled with analyze front-end to find out the basic problems/ difficulties in which the data taken from the cognitive and psychometric table of score in the end of the mid semester test of first semester and authentic assessment.

The result shows that problems in receptive and productive skills are about the text contentrelated reading, grammar, discourse markers, literal meaning, implications, and rhetorical relationship. However, the cases are mostly directed to the content $(72 \%)$ and grammar $(56 \%)$ of 72 respondents.

\section{DESIGN STEP}

The form of activities here involves possible vocabulary sources like vocabulary books, readers (other students and teachers), dictionaries, and corpora (Thornbury, 2007, pp. 75-76). Furthermore, they also involve digital online or offline sources. Activities here can be also meant by presenting vocabulary, using translation, illustrating meaning, explaining meaning and highlighting the form meaning (Thornbury, 2007, pp.75-91). And the next discussion should be described examples of presenting vocabulary in general through real things, pictures, action/gestures, definitions and situations which can be done in spoken or written forms, but then again, the limitation of page makes only few examples are given.

\section{PRESENTING VOCABULARY SESSIONS USING MEDIA (DEVELOP STEP)}

After defining and designing, here are some examples of the steps of using additional media in the classroom activities which are combined with the student's textbook in its chapters. The chapters indicate the Based Competence and each consists of 9 (nine) activities, they are; warmer, vocabulary builder, pronunciation practice, reading, vocabulary exercise, text structure, grammar review, speaking, writing, and reflection. However, the addition has purpose to complete the book's presence, not to substitute it, hence, it might have function to illustrate, explain or highlight the form meaning as stated above if it's held during the class, or 
as brainstorming as well as recalling the previous knowledge before the class. It may also become enrichment activities after the learning process with teacher's guidance.

\section{A. Based Competence 3.4 and 4.4, Descriptive Text of Historical Places}

1) Activity: warmer

As a warmer, sorts of pictures can be really helpful.

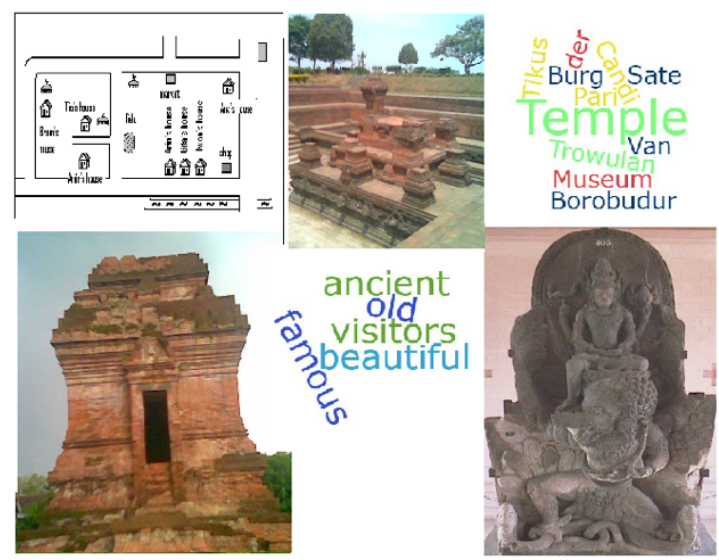

Figure 1. relevant pictures are given to illustrate the questions that creating better understanding.

2) Activity: Writing

The words/phrases in the box above are the definition or synonym that written in misspelled words and completed with the part of speech.

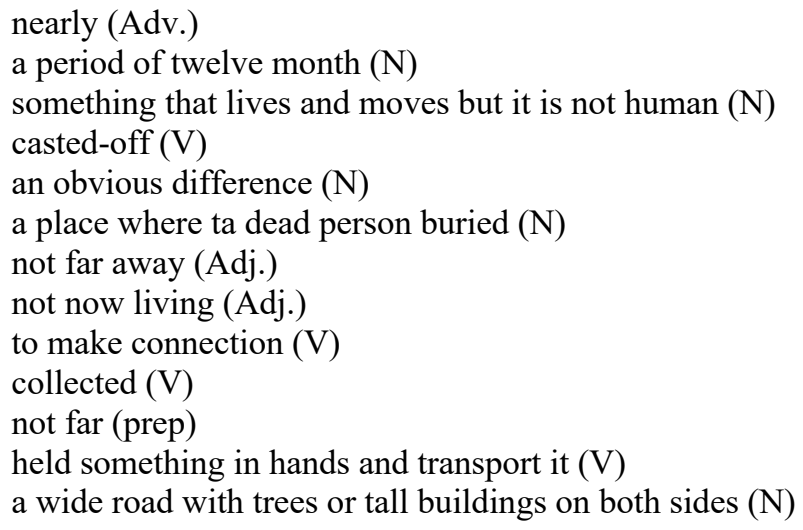

Figure 2. using more detail definitions/ synonyms to explain the meaning of words/ phrases that used in a text.

\section{B. Based Competence 3.5 and 4.5, Announcement (of school activities)}

Activity : Vocabulary Builder

Students can be asked to go online with acknowledgement before the classroom activities to bring their gadgets or laptop individually to discover their general knowledge of the topic. In this activity, teacher can open www.socrative.com and prepare the quiz to be launched 
on the D-day. The type of the quiz can be chosen, whether she/he prefers to have the multiple choices, true/false or short answer.

During the learning process, teacher can open the website with logging in as the teacher and ask the students to join the specific class that the teacher has opened as the student. When everything is ready, the students start to give their answer while the teacher is monitoring their activities and in the end of the sessions, she/he can save the result in the form of PDF (individually or classically) as well as in worksheet. Discussion is a must to be held after the activities that the teacher has opportunity to give feedback.

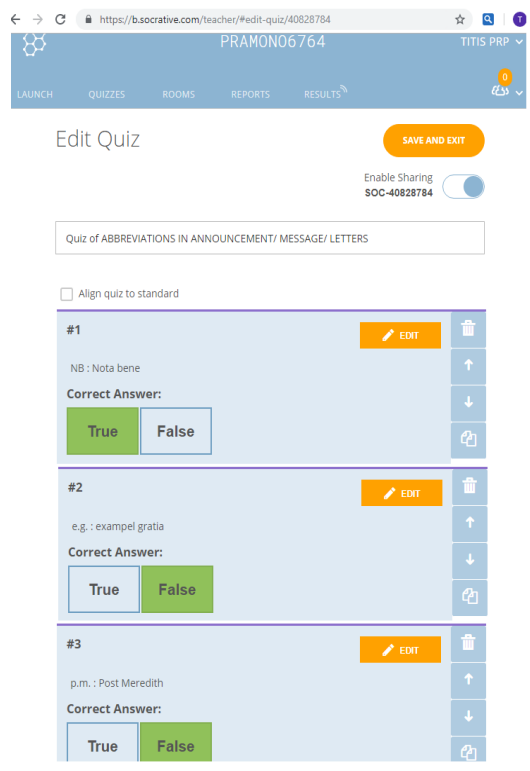

Figure 3. a layout of the Socrative webpage (A true/false Quiz of common Abbreviations)

Figure 3 has the function to widen the students' knowledge of common abbreviation related to announcement

\section{Based Competence 3.8 and 4.8, Narrative Text}

\section{Activity : Vocabulary Exercise}

There are some affixes can be exercised by the teacher to make students have more valuable experience on their study of vocabulary. This kind of material can't be found on the list of based competences of 3 (three) levels in senior high, however, students' understanding of the topic may help them to enhanced understanding of any text.

\begin{tabular}{|c|c|c|}
\hline & & $\begin{array}{l}\text { Use the affixes in the previous list before/after these roots } \\
\text { (according to the order on the list) so that they perform a new } \\
\text { meaningful words! } \\
\text { 1. happy } \\
\text { 2. quick } \quad \text { to become quing happy } \\
\text { 3. allot } \quad \text { a small piece of ground }\end{array}$ \\
\hline \multirow{2}{*}{\multicolumn{2}{|c|}{$\begin{array}{l}\text { Here is a list of Affixes (Prefixes and } \\
\text { Suffixes)! }\end{array}$}} & $\begin{array}{l}\text { 4. continent } \\
\text { 5. base }\end{array}$ \\
\hline & & 6. instant $\quad$ immediately \\
\hline -ness & un- & 7. tidy ${ }_{\text {not tidy }}$ \\
\hline -en & im- & 8. possible $=$ it can't happen/achieve \\
\hline -ment & in- & $\begin{array}{l}\text { - causing problems } \\
\text { unable to read/ write }\end{array}$ \\
\hline & il- & relevant $\quad$ not related to s.t discussed \\
\hline & ir- & print $\quad$ to be print again \\
\hline
\end{tabular}

Figure 4. Practice of word formation 


\section{CONCLUSION}

Based on the findings, analyses, theories and facts have been discussed above, vocabulary sessions can be added to enhance the materials in the official textbooks of National Curriculum. Hopefully, the students will widen their perspective of the knowledge and have more improvement for the positive progress of their capacity. In fact, there are still more activities to support good atmosphere of the learning process, however, evaluation, revise and review of the materials should be continuously done, especially to present a specific supplement book for the better.

\section{REFERENCES}

Anderson, R. C., \& Freebody, P. (1981). Vocabulary knowledge. In J. Guthrie (Ed.), Comprehension and teaching: Research Reviews.

Haddad, R. H. (2016). Developing Learner Autonomy in Vocabulary Learning in Classroom: How and Why can it be Fostered? Procedia - Social and Behavioral Sciences. https://doi.org/10.1016/j.sbspro.2016.10.106

Marianne, C.-M., \& Olshtain, E. (2000). Discourse and context in language teaching: A guide for language teacher. In The United Kingdom. New York: Cambridge University Press.

Nagy, W. E. (1988). Teaching vocabulary to improve reading comprehension. Illinois: National Council of Teachers of English.

Peraturan Menteri Pendidikan Nasional No.37 Tahun 2018 tentang Kompetensi Dasar SMA.

Rakhmadie, Sabrony. (1986). Buku materi pokok vocabulary :PING 4432/2 SKS/modul 1-3 dan modul 4-6 /oleh Sabrony Rachmadie. Jakarta: Karunika Universitas Terbuka.

Richards, J. C., \& Renadya, W. A. (2002). Methodology in language teaching: an anthology of current practice. New York: Cambridge University Press.

Şen, Y., \& Kuleli, M. (2015). The Effect of Vocabulary Size and Vocabulary Depth on Reading in EFL Context. Procedia - Social and Behavioral Sciences. https://doi.org/10.1016/j.sbspro.2015.07.546

Thornbury, S. (2007). How to teach vocabulary. Malaysia: Pearson Longman. 